\title{
What Makes the Qur'ānic Narratives Cohesive? Systemic Functional Linguistics-Based Analysis of Reference Role: Some Reflections
}

\author{
ZAID ALAMIRI and PETER MicKAN (University of Adelaide)
}

\begin{abstract}
The present study aims to analyse reference, as a cohesive device, in some of the Qur'ānic narratives of Abraham and Moses in ten suras. The study is based on, and limited to, HALLIDAY \& HASAN's concept of cohesion as a semantic relationship realized through grammatical and lexical devices. Such cohesive role of reference is implicitly treated and discussed within the topic of pronouns antecedents in the Arabic linguistic tradition. Reference resources in the Qur'ān are diverse but the scope of this study was confined to only the personal and demonstrative components of reference. The analysis showed that personal reference (of the third person forms) was the most frequently used in these narratives. Its salient features, of multiple referents and cumulative effect, contributed to the economy of language use and finally enabled the cohesion of the text. The demonstrative reference was less frequent, yet it provided, through its function of connecting various text parts, an additional contribution to the narratives' cohesion. In general, reference, as one element of the textual metafunction, has played a major role in the text creation in terms of cohesion and coherence.
\end{abstract}

Key words: Reference, Cohesion, Qur'ānic narrative, Systemic Functional Linguistics

\section{Introduction}

The focus of this paper is exclusively on one resource of cohesion (i.e., reference) viewed from, and based on, HALLIDAY \& HASAN's 1976 Cohesion in English. It is an exploration of how reference, a grammatical cohesive device, contributes to building cohesion and coherence in the Qur'ānic text of these narratives. Based on that, the review of the concept of reference in Arabic is limited to the traditional resources. The analysis of the relevant material, however, will be carried out in accord to Systemic Functional Linguistics ${ }^{1}$ (henceforth SFL).

1 SFL is a socially oriented (sociosemiotic) theory that considers language as a source for meaning making (meaning potential). Its distinctive features are: functional (its organization reflects the functions to serve in the human society); systemic (a set of unlimited options and choices of creating meanings, rather than as a set of rules); and contextual (every text, spoken or written, takes place in a context of situation). Language is tri-stratal: semantic, lexico-grammar, and phonology, in which meaning (semantic) is realized by wording (grammar \& vocabulary), which is realized by sound (phonology). At 
As to cohesion and coherence of the Qur'ānic text, two contrasting views have been dominating. ${ }^{2}$ The Muslims' view, which is religiously oriented ${ }^{3}$ (MIR 1988: 40), had fallen short of realizing the textuality of the Qur'ān. ${ }^{4}$

\subsection{Text, cohesion and coherence: concept and elements}

A very brief account of text, together with its two closely related features, cohesion and coherence, will be given here.

Text refers principally to any stretch of language in use, "of whatever length, that does form a unified whole" (HALLIDAY \& HASAN 1976: 1). This definition makes explicit that text is not a grammatical (structural) unit, like a sentence or a clause where size matters; actually "most texts extend beyond the confines of a single sentence" (ibid.: 7). Text is rather a unit of language which differs "from a sentence in kind" (ibid.: 2). In other words, it is a "semantic unit", characterized by texture that differentiates it from non-text, simply because it "functions as a unity with respect to its environment" (ibid.: 2). Its unity is a unity of meaning in context (ibid.: 293); that is, a context in which it is "doing some job [...], as opposed to isolated words or sentences" (HALLIDAY \& HASAN 1989: 10). And without a context of situation, text cannot carry out social interaction (communication) among the members of any speech community (ibid.). Text then is an object of social exchange of meanings because "every kind of text in every language is meaningful" (ibid.: 11). In a nutshell, "any piece of language that is operational, functioning as a unity in some context of situation, constitutes a text" (id. 1976: 293).

\subsection{Cohesion and cohesive relations}

Since text is a unit of meaning, its components or parts are "held together" by a variety of internal forces that establish the cohesive relations (id. 1976: 4). These forces are defined as a network of relationships, arising from grammatical elements (reference, substitution, ellipsis and conjunction) and lexical elements (reiteration and collocation). And every language has these linguistic resources "for linking one part of a text to another" (HALLIDAY \& HASAN 1976: 10, 18; 1989: 48). The function of the cohesive devices is to make the text achieve its communicative force and effect, because they are the primary determinants of whether a set of sentences do or do not constitute a text (ibid.: 2, 10, 18). Though cohesion is realised by lexico-grammatical devices, it is constructed semantically in that "it refers to relations of meaning that exist within the text, and that define it as a text" (ibid.: 4). Ex-

the stratum of semantic, every mode of meaning, at the level of the clause, simultaneously consists of three metafunctions: experiential, interpersonal, and textual.

2 That is, Western Qur'ānic scholarship denies and questions this issue, whereas Muslim scholarship defends and confirms.

3 It is based on the idea of inimitability (الإعجاز), taken as indisputable fact. This inimitability idea is extensively elaborated and discussed in many of rhetoric and exegetical literature.

4 It means that the Qur'ān is a text, produced within a definite culture, and later on it became a producer of a new culture (i.e., historical context). Linguistically speaking, it has the features that are found in any other text. Denying its textuality leads to a freezing of its message meanings. ABŪ ZAYD (1995, 1996, 2003) extensively discussed and elaborated this issue. 
pressed differently, "cohesion occurs where the INTERPRETATION [emphasis in original] of some elements in the discourse is dependent on that of another"5 (ibid.). Though cohesion helps create text by providing its texture, it actually represents one part of the text-forming component (i.e., textual metafunction) of the linguistic system (ibid.: 298299). Finally, one can see that neither grammatical nor lexical elements can be cohesive by itself, but only when they are interpreted through their relation to some other element in the text; as this leads to formation of a cohesive tie when two elements in a text are related, and thus contributing to the text unity. In this way, cohesion expresses the continuity that exists between one part of the text and another (ibid.: 299).

Coherence, like cohesion, is another semantic feature of text. It is not realized by lexico-grammatical devices; rather by network of relations that organizes the text. There are differences on the interpretation of its nature and function in the text. ${ }^{6}$ For HALLIDAY \& HASAN, coherence expresses the coherence of the text with its context of situation; meanwhile, cohesion expresses the coherence of the text with itself (1976: 23).

Exploring the linguistic resources employed by the Qur'ānic text, and in particular the cohesive devices, ${ }^{7}$ helps understanding the Qur'ānic text. Through analysis of the way these devices are managed this enables us to reveal to what extent the text bears features of cohesiveness and coherence.

\section{Reference in the Arabic linguistic tradition}

The term 'reference' as such was not known to Arab linguists. It was implicitly dealt with in their intensive analysis of pronoun uses, and in particular in defining the 'interpreter' (referent) of the third person pronouns. ${ }^{8}$ Linguists' analysis of the pertinent points of reference bears relevance to many of its contemporary notions, as we are going to show. Reference, in Arabic, is realized through personal, demonstrative and relative pronouns as well as the definite article. The first two are the most frequent in the Qur'annic usage; therefore the study is confined to, and elaborates on, only these two elements. The review of the topic follows both perspectives of the Arabic linguistic tradition and Hallidayan SFL; analysis of the relevant material, however, will be limited to the second.

5 Frequently the term of 'presupposition' is used. It means that one element presupposes 'the other, in the sense that it cannot be effectively decoded except by recourse to it. When this happens, a relation of cohesion is set up, and the two elements, the presupposing and the presupposed, are thereby at least potentially integrated into a text (HALLIDAY \& HASAN 1976: 4).

6 It is beyond the scope of this study to discuss these points (extensively elaborated in, for example, BAKER 1992; FAWCETT 1997; TABOADA 2004; TANSKANEN 2006; CHRISTIANSEN 2011, among others). As regards the Qur'ān, most western critiques were levelled at this concept. Muslims' understanding of the concept centred on 'thematic unity' in that ayahs of a certain sura revolve around (a) definite topic(s) or theme(s). This implicitly indicates the presence of a logical order between these ayahs that link them together (for more, see EL-'AwA 2006).

7 Cohesion represents the non-structural system of the textual metafunction (text-creating) components or systems.

8 In traditional literature (linguistic and exegetical) it is known as الضمدير , and in contemporary literature as الإحالة. 
Pronouns, the medium on which referential relations are built, occupied and received ample attention in linguists' treatises on language, as well as in the Qur'ān exegesis. Being ambiguous, pronouns need something (referent) to identify and interpret them. Personal pronouns, in particular, for being of a wide scope of use in the speech, were examined thoroughly. Since our analysis is elaborated in light of SFL, only some relevant points, of the Arabic linguistic tradition, will be discussed here; and these include: some features of personal pronouns; phoric relations and the concept of aboutness. Other points related to the agreement between the pronoun and the referent (number, gender, etc.) are not included. Also, it is worth mentioning that we used SFL terminology, though not mentioned in the Arabic linguistic tradition, as regards the types, and directions of referential relation.

\subsection{Personal pronouns: two sides of brevity and ambiguity}

First of all, pronouns in Arabic are morphologically and syntactically diverse in terms of person, gender and number (HASAN 1974, 1: 217-279). As regards their position inside the text, they are of two kinds: separate (free standing), or bound (attached) to nouns, particles, and verbs. The role the personal pronouns play in reference relations is sophisticated and multi-tiered. This relation was a shared area of concern for linguists and Qur'ān exegetes, the focus of which was to reveal how pronouns hold the text parts together through defining the grammatical and semantic links between these parts.

Pronouns are known of having two salient semantic features, that is, brevity and ambiguity. Grammarians recognized that pronouns' role in speech is to render the text more concise, thus keeping the discourse running and well-connected (al-'Alawī [d. 1348] 2009, 1: 444). Ibn $\mathrm{Ya}^{\mathrm{c}} \overline{\mathrm{I}} \mathrm{s}$ (d. 1245) pointed out that brevity enables writers to "dispense with the frequent usage of explicit nouns and hence contributes to certainty of meaning" (2001, 2: 292). This function creates a cohesive textual link between text elements. as-Suhaylī (d. 1185) stresses that whenever a speaker "needs to repeat an already mentioned thing (noun), he turns towards pronouns to substitute them (nouns)" because pronouns "are so abundant in the speech of Arabs amounting to sixty kinds of free standing (separate) and bound (attached)" (1992: 170-177). Q 33:35 is a good example of how one pronoun ("to them', له ) dispensed with the repetition of twenty nouns.

On the other side, pronouns are inherently ambiguous because they "point to everything, animate and inanimate; and the definiteness, required to remove this uncertainty, comes not from themselves, but through their referents" (al-'Astarābād̄ī [d. 1289] 1996, 2: 406). This is more relevant to the third person (absent) pronoun, which, as al-'Astarābādi states, "acts as substitute (for a noun) because the meaning it refers to is realized indirectly through its referent and not by itself (pronoun)" (ibid., 3: 148). Linguists drove home the point that clearing up the ambiguity of an absent pronoun requires a referent (interpreter), which can be textually inferred (al-'Andalusī [d. 1344] 1993, 2: 252). The reason is that the ambiguity of a pronoun, unless a referent exists to remove it, persists in the text. To that effect, al-'Astarābādī (1993, 2: 406) added that "absent pronoun necessitates a referent to come before it; and if it does not, the pronoun retains its ambiguity until its referent comes after it". In other words, unlike noun or adjective, pronouns receive their signification from the referent to which they refer; and in most of the cases, the referent is an explicit noun (lexical referent) or a stretch of a text (text referent) (HASSĀN 1994: 111). The grammari- 
ans realized that the first and second pronouns (speakers and addressees) do not need referents because they are present in the discourse and understood from the context (Ibn al-

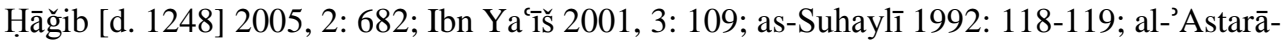
bādīi 1996, 2: 402).

In ellipsis, a similar emphasis on the presence of a referent is also given. In this regard, Sībawayhi comments that you delete a noun only after "you know that the listener knows whom or what you are talking about, and that you mean something in particular (Sībawayhi 1988, 2: 6). This means that ellipsis is not 'allowed' unless there is a referent to the elided thing. This partial review showed that Arab grammarians were aware of the reference relation between a pronoun (reference item) and its referent, and the tie this relation establishes between elements of a text.

\subsection{Phoric relations}

This refers, in particular, to the kinds of reference, and the distance between the reference and its referent. Referents are classified into two general kinds: endophoric (present in the text) or exophoric (unmentioned) understood from speech context or circumstantial context (al-’Andalusī 1993, 2: 252; Ibn Hišām [d. 1360] 2000, 1: 169).

\subsubsection{Endophoric referents}

Endophoric referents are divided into two types, based on the place of the element they refer to: anaphoric (pointing to a preceding element) and cataphoric (pointing to a following element). Anaphoric relation is the most common and frequent reference relation in the Qur'ān. Examples are abundant, and for sake of brevity we just mention two examples: in Q 33:35, one pronoun referred back to twenty referents (nouns); however, Q 2:15 is a different case where there are thirty pronouns falling back on one referent. Meanwhile, the cataphoric relation was considered an exception to the general rule of anaphoric. The salient case of this kind is the use of the damīr $a \check{s}-\check{s} a^{\prime} n .^{9}$

\subsubsection{Special case of endophoric referent}

There are cases where the referent is not found inside the text; it is implicitly understood as if it were there. Put differently, there is a textual clue inside the text pointing to the referent.

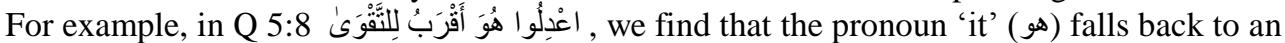
unmentioned, rather deleted, element derived from the verb (اعدلو), which is equivalent to the verbal noun (العدل); so the ayah should be read اعدلوا فالعدل اقرب للتقوى (al'Astarābād̄ī 1996, 2: 403). In other words, the referent is implicitly understood and inter-

9 It refers to the third person pronoun that should be exclusively singular (not dual or plural) to serve this function, coming in a separate or bound forms; also, it should be positioned initially in the clause. Unlike anaphoric pronouns, its referent should be a (declarative, i.e., statement) clause that comes after it, which serves both as a referent and an exponent of it. The pronoun has rather rhetorical importance - to draw the addressee's attention to what is coming later (al-'ASTĀRĀBĀDİ 1996,2: 464-465; IBN ALHĀĂIB 2005,1: 450). It is known also by other denominations like the 'pronoun of the story'. Its occurrence is abundant in the Qur'ān. 


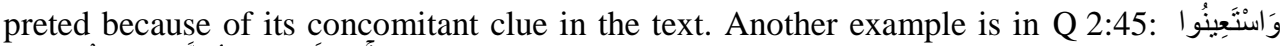

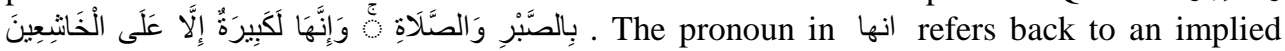
referent inside the text; the referent, a verbal noun (i.e., assistance, الاستعانة , derived from the verb استعينوا), was substituted by the pronoun working as a reference item.

\subsubsection{Exophoric referents}

The exophoric reference is very frequent in the Qur'ān, as the context of situation defines and interprets the referent. The identification of such referents was easily arrived at by the addressees of the time, since they were known to them. This is evident in two examples:

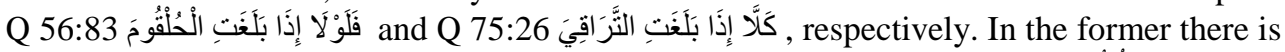

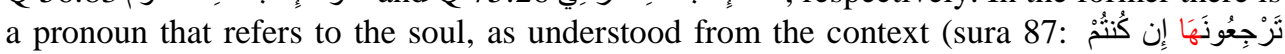
صَادِقِنَن (ص) In these two suras, the context (exophoric) points to the 'soul', as being the referent because there is a semantic relation between the utterances 'throat' in the former ayah and 'clavicles' in the latter, associated with the meaning of both ayahs (al-'Astarābādī 1996, 1: 405; az-Zamaxšarī 2009: 1080, 1126). In support of the contextual clue, az-Zamaxšarī (ibid.: 1080) cited a Ḥātim al-Ṭâ̄î̀ verse. ${ }^{10}$

\subsection{Range and distance}

A considerable account was also given to the aspects of range and distance for the importance they have in establishing the ties between parts of a text; as these ties assure the certainty of the meaning essential to text coherence. It lies outside our scope to give details of it. The general rule is that the referent should be proximate to the pronoun, i.e. in the immediate preceding sentence. However, with existence of a clue, the referent may be far removed from the pronoun (reference item) (HASSĀN 1993: 135; 2005: 185-186). And when there are two or more (multiple) referents, the nearest among them is taken as the

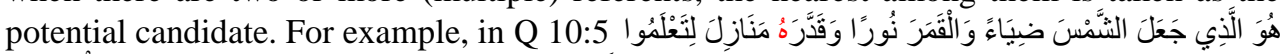

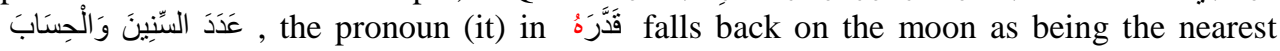
referent (al-'Andalusī 1993, 1: 341; al-'Astarābādīi 1996, 4: 2). Finally, it is worth mentioning that the proximate rule is not invariant, and cannot be applied to all situations of pronoun reference in the Qur'ān. And this reflects the different interpretations exposed in the exegetical works; a point we hint to some of its aspects in the following section.

\subsection{Aboutness}

Having multiple reference items (pronouns) raises a problem of determining which referent each of these reference items falls back on. As a general rule, linguists, realizing the semantic side, consider that the one the text revolves around is the relevant. For example,

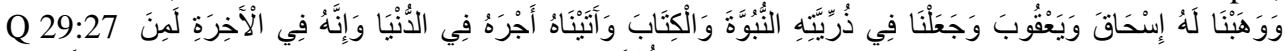
should fall back on Abraham mentioned in

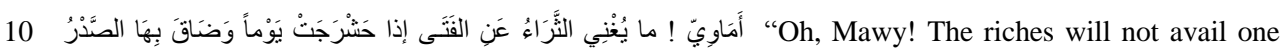
when someday [his soul] rattled [in the throat] and the chest got tightened with it [the soul]" (my translation, ZA). 
the earlier ayahs (starting from number 16), and not on Isaac or Jacob, though they are close to the pronoun, because Abraham is the focus of the story. Other examples are found in Q 15:16-17 and Q 100:6-8. This reflects actually the linguists' understanding of the semantic relations of the text. Such interpretation is also argued for Q 62:11: أَوْ لَهْوَا انفَضُّو إِلَيْهَا (al-'Andalusī 1993, 1: 341); here the rule of proximity is not followed because the (far) referent about which the speech revolves is the pertinent one in the message. The same is also found in the case of annexed construct and the second noun of the construct case (المضاف والمضاف اليه), where the pronoun falls back on the distant part, because it

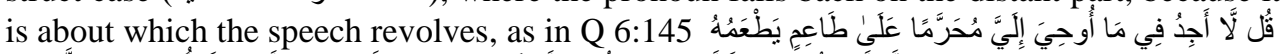

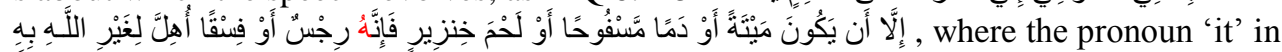

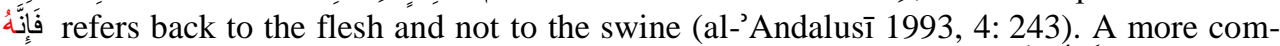

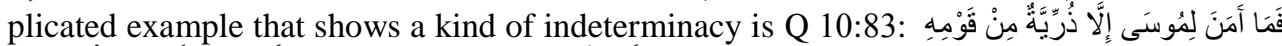

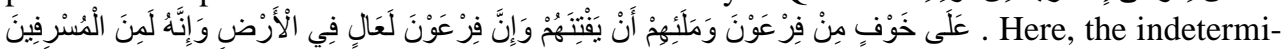

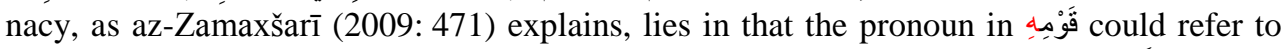

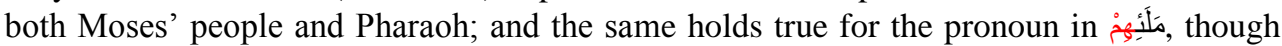
az-Zamaxšarī mentions that the pronoun falls back on Pharaoh only (ibid). However, al'Andalusi (1993, 5: 182) argues that the pronoun of falls back on Moses and not on Pharaoh, because Moses is the relevant referent. Finally, in Q 5:96 the pronoun in 'its food' falls on one part of the referent, the sea (the second part of the construct case) (ibid., 4: 26).

This notion of 'aboutness' occurs in cases of multiple referents. For example, in

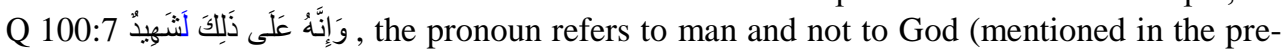
vious sura, Q 100:6), because the man is the focus of the discourse. Another sound example that shows that inconsistency and meaning problems are inevitable, is ayah Q 20:39 : . The problem of inconsistency stems from that the bound pronoun could fall back on both Moses and the Ark. azZamaxšarī (2009: 655) argues that all the pronouns should refer back to Moses, otherwise ayahs fail to show coherence. ${ }^{11}$ Besides, we can add that since Moses being the focus (aboutness) of the text, pronouns should fall back on him (Moses) and not on the Ark, thus avoiding the semantic inconsistency.

It follows that indeterminacy abounds in the Qur'ān, and if any semantic inconsistency may arise, textual or contextual clues help resolve the referential problem (al-'Andalusī 1993, 1: 540). An interesting example is Q 25:50-52, where the pronoun in صَرَّفْنَاهُ , based on the proximate rule, should refer back to the second clause of ayah 48 and ayah 49 (rain water). However, it may be related to the Qur'ān, unmentioned but understood from the context. By the same line of argument, one can hold that the pronoun in in ayah 52, that bears relevance to the ayah 50, can be understood contextually to refer to the Qur'ān. In interpreting the referential relations in these ayahs, az-Zamaxšarī explains it as follows: لقد (2009: 749), seeing that the Qur’ān, contextually understood, is the referent; although he did not exclude the other option of referring to the rain water, as he said "it is said that we distributed rain water" (ibid). ${ }^{12}$ And he made the same conclusion as

11 This shows that cohesion and coherence are inseparable; on the other hand, it makes explicit that exegetes were fully aware of the semantic relations 'working' in the text under study.

12 The verb صَرَّفْنَا in this specific ayah means both 'we explained' when it is collocated with the Qur'ān, and also 'we distributed' when is collocated with water. In other ayahs it is collocated with the preposi- 
regards بِ in ayah 52. Viewed semantically, the referent should be the Qur'ān, understood from the context, because such meaning can be found in other places where the verb صَرَّفَّا is used in collocation with the Qur'ān as, for example, in Q 18:54. In summary, it makes sense to interpret the Qur'ān as being the referent in light of the context rather than using the proximate rule; similar examples are in Q 11:25-28; 82-83, and Q 21:57-58.

Finally, we have to mention that the above discussion is only a brief account of some of the referential relations in the Qur'ān, because our focus, as explained earlier, is to explain such relation in light of SFL principle of cohesion, and not to treat reference-related issues in Arabic.

\section{Reference in contemporary linguistics}

\subsection{Definition}

Reference is a notion which has been discussed by philosophers and linguists alike. In philosophy, it is limited to a "relationship between a concept or state of affairs (the referent), and any word or phrases which designate the same (referring expression)" (CHRISTIANSEN 2011: 53). In other words, it is the traditional semantic view of a relation between expressions in a text and entities in the world (BROWN \& YULE 1988: 199); and this view has logical, epistemological and metaphysical implications. The linguistic view is much wider in that everything can refer. ${ }^{13}$ As to our study, we discuss it in light of the explanation presented in HALLIDAY \& HASAN's book Cohesion in English (1976). It states that every language has certain items which "instead of being interpreted semantically in their own right, they make reference to something else for their interpretation" (1976: 31); because it will be necessary, "in any connected passage of discourse [.... to refer back to something that has been mentioned already, making explicit the fact that there is identity of reference between the two" (ibid.: 305). It is the "semantic content rather than the content itself" that is of importance to the texture of a text, because such a relation "creates texture not because the interpretation has become available, but because the interpretation clinches the fact that a particular kind of semantic relation obtains" (ID. 1989: 78).

\subsection{The cohesive role of reference}

Reference is being considered as one set, among others, of grammatical resources employed in "marking textual status"; where textual status of reference is known as that of identifiability (emphasis in original). And the identifiability is related to the speaker's judgment of whether or not "a given element can be recovered or identified by the listener?” (HALLIDAY \& MATTHIESSEN 2004: 549-551). The recovery of this identity is provided by the preceding text or, in effect, "the system of meanings [...] as the text unfolds"

tional phrase في هذا القرآن, as explained above.

13 It implies that 'natural language is much more flexible than the rigid propositions' of philosophers (CHRISTIANSEN 2011: 56).

JAIS • 16 (2016): 199-219 
(ibid).$^{14}$ In other words, these items "refer to how the writer/speaker introduces participants and keeps track of them once they are in the text" (EGGINS 2004: 33). Hence, these items "allow the speaker to indicate whether something is being repeated from somewhere earlier in the text or whether it has not yet appeared in the text" (THOMPSON 2004: 180). Though the relation these items establish is realized through the grammar, between elements that lack relatedness in forms or wording (HALLIDAY \& HASAN 1976: 32), they (the items) actually enter into a semantic one consisting of repetition of meaning; and in so doing, they function as cohesive devices (THOMPSON 2004: 180) because they create and maintain a tie between the text parts.

Summing up, cohesiveness of reference resides in the interdependence between a reference item and another (explicit) textual element required for its interpretation. Thus, the cohesion does not result from this relation; rather it "lies in the continuity of reference, whereby the same thing, serving as a resource of interpretation, enters into the discourse a second time" (HALLIDAY \& HASAN 1976: 31, 308). Finally, reference is but one element of the cohesion, which itself is one part of the text-forming component in the linguistic system, i.e., the textual metafunction (ibid.: 27). This metafunction comprises the resources the language has for creating text, and gives "the clause its character as a message" (HALLIDAY \& HASAN 1976: 27; HALLIDAY 1994: 37), helping thus in interpreting ideational \& interpersonal meanings. ${ }^{15}$ Reference operates along with a number of other elements of cohesion, both grammatical and lexical, to establish a web of semantic relations within the text. Together, these elements of cohesion express the non-structural dimension of the textual metafunction of the semantic system. ${ }^{16}$

\subsection{Reference items}

In English these items consist of personal and demonstrative references, definite article and comparatives. The first two are the most common. The first one is "reference by means of function in the speech situation, through the category of person", whereas the demonstrative reference "is by means of location, on a scale of proximity" (HALLIDAY \& HASAN 1976: 37). HALLIDAY \& MATTHIESSEN (2004: 556) argue that demonstrative pronouns "were probably the same as third-person forms, but they retain a stronger deictic flavor than the personals, and have evolved certain distinct anaphoric functions of their own". However, the personal pronouns play an important role in text cohesion and coherence (HALLIDAY \& HASAN 1976: 45), and not all of them are cohesive, because, as HALLIDAY \& HASAN (ibid.: 51-52), explained, there is a distinction between the speech roles (first and second person) and other roles (third person). Only the latter is inherently cohesive in that it refers anaphorically to a preceding item in the text and it has a characteristic feature of

14 This refers to the text unfolding as a message realized by the textual metafunction systems (see footnote 16 below).

15 Textual metafunction is called the enabling metafunction as it organizes the linguistic resources employed in the experiential and interpersonal metafunctions and presents them in a message.

16 The other components of this metafunction are the thematic system (Theme-Rheme), information system (Given-New), and thematic progression. 
being "cumulatively anaphoric" (ibid.: 51-52). This stems from its usage in avoiding the repetition of a previously mentioned noun or noun phrase.

\subsection{Domain of reference}

Domain of reference bears relevance to the features of the relation between a reference item and its referent. These are the direction, distance, and size of reference.

As regards the direction of reference, it is either exophoric pointing 'outwards', or endophoric pointing 'inwards', to identify a referent in a text. In the case of exophoric reference, which is the first to be evolved as a means of linking 'outwards' to some entity in the environment (HALLIDAY \& MATTHIESSEN 2004: 551), the identity presumed by the reference item is recoverable from the environment of the text. As such, it does not contribute to the cohesion of the text, because it only signals that reference must be made to the context of situation, linking the language to the external context (HALLIDAY \& HASAN 1976: 32-33, 37; 58-59; HALLIDAY \& MATTHIESSEN 2004: 522; THOMPSON 2004: 181).

In comparison to the exophoric type of reference, the endophoric is quite different in that it is more contributive to the cohesion than the exophoric. Secondly, it consists of two relations, anaphoric and cataphoric, that differ in their 'pointing' to the referent. The anaphoric, which is very common, points 'backwards'; and it is most cohesive because "the meaning that is being repeated has already been mentioned earlier in the text" (THOMPSON 2004: 181). That is, the recovery of the identity presumed by the reference item is derived from within the text itself; and hence its contribution to the cohesion is significant because a tie between the texts' passages is created (HALLIDAY \& MATTHIESSEN 2004: 552). It follows that the endophoric ties are "crucial to the texture of a text" because "cohesion would not be perceived, unless an endophoric interpretation of the implicit item can be sustained" (HALLIDAY \& HASAN 1989: 76). The cataphoric relation, which points "forwards' to a referent that is yet to be introduced (HALLIDAY \& MATTHIESSEN 2004: 552), is rare as compared with anaphora. And therefore it does not contribute to the cohesion of the text because the reference is within the structural frame of the sentence (HALLIDAY \& HASAN 1976: 56). ${ }^{17}$

The second parameter is the range (distance) of reference. The most common pattern in anaphora is that the referent is found in the immediately preceding sentence (HALLIDAY \& HASAN 1976: 2-3, 15). However, the referent can also be further removed from the reference item (ibid.: 14-15). The most important thing is that reference is generally made to the nearest compatible candidate. With cataphoric reference the range is shorter, where the referent comes immediately after the reference item. Finally, the size of a linguistic referent varies from as small as a single element to as large as a whole discourse. Pronouns commonly refer to a single item or a single nominal group and demonstratives often refer to larger blocks of language.

17 Two comments are necessary to mention. First, this is valid only to the personal form (exclusively personal pronouns and not possessive pronouns), which refers cataphorically to what is known as 'dummy pronoun', an equivalent of the Arabic pronoun of $a \check{s}$-ša'n; secondly, demonstratives refer cataphorically in genuinely cohesive way (HALLIDAY \& HASAN 1976: 56), as our analysis will show. 


\section{Text analysis}

\subsection{Narratives of Abraham}

The narrative of Abraham is mentioned in the Qur'ān in nineteen suras, varying in size from one ayah (Q 2:260; Q 4:125) to twenty or more (Q 26:69-89; Q 6:74-90; Q 37:83113). These narratives revolve around one main topic in which Abraham calls his people to the belief, and unity of God. Here, we analyse ten of these suras; it is worth pointing out that these suras introduce segments or passages (ayahs) and not a whole narrative of Abraham. This is to say that there is not a complete narrative of Abraham, rather segments (ayahs) of it mentioned in different suras. The passages (ayahs), which represent the Abraham narrative in each sura, were arranged in a descending order of length to see how reference works in both long and short texts.

\begin{tabular}{c|c|c|c|c|c}
\multirow{2}{*}{ sura \& ayah no. } & \multicolumn{5}{|c}{ Referents and their respective number in each sura } \\
\hline & Abraham & His people & Idols & His guest & His wife \\
\hline $37(83-113)$ & 24 & 7 & 1 & & \\
\hline $21(51-73)$ & 16 & 14 & 12 & & \\
\hline $26(69-89)$ & 5 & 2 & 5 & & \\
\hline $6(74-90)$ & 18 & & & & \\
\hline $29(16-27)$ & 13 & 1 & 1 & & \\
\hline $51(24-34)$ & 11 & & & 9 & 3 \\
\hline $2(124-134)$ & 9 & 5 & & & \\
\hline $19(41-50)$ & 7 & & & & \\
\hline $15(51-60)$ & 5 & & & 5 & \\
\hline $11(69-76)$ & 10 & & & & 3
\end{tabular}

Table 1: Personal references in Abraham narratives

\subsubsection{Personal reference}

For the sake of space, only the common referents mentioned in the stories were displayed; the other less frequent will be mentioned in the discussion.

Table 1 displays three important aspects. Firstly, the noticeable thing is the occurrence of multiple referents, among them Abraham is the most frequent one across the passages. This multiplicity of referents strengthens the semantic networks they created, and thus holding text parts (here the different ayahs) together, which establishes cohesive ties ena- 
bling the text formation and understanding (process and product). Implied within this is that the repetition of any referent, of them, leads to a cumulative effect of semantic networks of the text cohesion. It is worth mentioning that some referents are not common in the narratives, and therefore not mentioned in the analysis; however, on their turn, they contribute to text cohesion inside their respective narratives. For example, the referent 'our messenger' in Q 11 has six references falling back on Abraham (anaphoric). There are also cases, such as in Q 29, in which a referent, (God, for example), was mentioned twelve times with twelve antecedents not referring to the same specific referent. This falls within a lexical (of repetition) rather than a grammatical cohesive relation. Anyhow, the cumulative effect, whether from repetition or reference, significantly contributed to the cohesion of the narrative. Secondly, as regards phoric direction, all references are endophoric, and in particular, anaphoric; however, the exophoric are found only in three ayahs of Q 19:42, 48-49 (all refer to the idols worshipped by his people, as they are contextually understood). Finally, the personal references are of two kinds, the personal pronouns, which are the more frequent, and the possessive determiners (possessive adjectives) that come in second order of frequency.

\subsubsection{Demonstrative reference}

Demonstrative references are, in general, less frequent than the personal references; their role cannot be underestimated for they, through connecting various text parts, significantly contribute to text cohesiveness. Their total number is 26 pronouns. They are of two kinds, one which refers back to a single lexical item that comes before it (anaphoric); and these are found in Q 6: 76-77-78, and Q 21:63, where the pronoun 's 'this', mentioned in each ayah, refers to an immediate referent coming before it. The second one is the text reference in which the pronoun falls back on a whole text (of one ayah or more) that consists of clause complexes. ${ }^{18}$ Examples in this narrative are found in eight suras as shown in Table 2 (see next page).

Two things are highlighted here; first of all, references are anaphoric, with significant implications for text cohesion; only one example of exophoric reference found in Q 6:89, هؤلاء 'these', which refers to a referent understood, from the context, by the audience of the time. Secondly, in terms of range and position, the majority of these text references are far removed from their respective pronouns; meanwhile the remainders-indicted with the asterisk (*) — consisting of clause complexes - are found in the immediate environment of the same ayah coming before their relevant demonstrative pronouns.

18 That is, they consist of more than one clause in accord to SFL terms in defining the structure of the ayah. 


\begin{tabular}{c|c|c|c|c}
\multirow{2}{*}{ sura no. } & \multicolumn{4}{|c}{ Demonstrative reference (numbers refer to the ayahs inside each sura) } \\
\cline { 2 - 5 } & this & that & these & those \\
\hline 37 & $(106 \rightarrow 102-105)$ & $(105 \rightarrow 104)$ & & \\
\hline 21 & $(59,62 \rightarrow 58)$ & $(56 \rightarrow 56)$ & $(65 \rightarrow 58-63)$ & \\
\hline 26 & & $(74 \rightarrow 71)$ & & \\
\hline 6 & & $\left(83 \rightarrow 76-82 ; 84^{*} ;\right.$ & $(89-90 \rightarrow 84-87)$ & $(82 *)$ \\
\hline 29 & & $\left(16,19,24^{*}\right)$ & & $(23 *)$ \\
\hline 51 & $(30 \rightarrow 28-29)$ & & & \\
\hline 2 & $(126 \rightarrow 125)$ & $(134 \rightarrow 132-133)$ & & \\
\hline 19 & & & & \\
\hline 15 & & & & \\
\hline 11 & $(72 \rightarrow 71 ; 76 \rightarrow 74)$ & & & \\
\hline
\end{tabular}

Table 2: Text reference of demonstrative pronouns $(*=$ explanation inside text)

\subsection{Moses narratives}

Moses as a noun is mentioned in thirty four suras, and as a narrative it is mentioned in over ten suras of the Qur'ān, varying in length from short passages (one or two in suras $4 ; 5 ; 14$; and 17) to long passages (90 in sura 20; 58 in sura 26; 54 in sura 7; 41 in sura 28, and 31 in sura 40).

We analysed narratives in Q 7; Q 10; Q 20; Q 22; Q 26 and Q 28, as being long segments, and some of the short segments in Q 2; Q 5; Q 11; Q 27 and Q 43. The narratives are arranged in a descending order of the number of ayahs. They are distributed over three tables on the basis of having common referents across the narratives. Moses narrative in Q 18, consisting of two sections, was put in a separate table (Table 3). The two consecutive sections reflect this variation in the referents. The same is applied to narratives in Q 2 and Q 5.

\subsubsection{Personal reference}

Many points, in these stories, which were looked over briefly in the preceding section, are examined in some detail. These have to do with the multiple referents, interchangeable referent forms, and finally the unmentioned referents. 


\subsubsection{Multiple referents}

Table 3 shows only the prevalent personal referents across the narratives, among them Moses is the most frequent-in segments of suras (Q 7; Q 20; Q 28; and Q 26), on which a large number of reference items fall back. These segments are longer than the others in suras Q 43; Q 27 and Q 10.

\begin{tabular}{c|c|c|c|c|c}
\multirow{2}{*}{$\begin{array}{c}\text { sura \& ayah } \\
\text { no. }\end{array}$} & \multicolumn{5}{|c}{ Referents and their respective number in each sura } \\
\cline { 2 - 6 } & Moses & Sorcerers & $\begin{array}{c}\text { Moses' } \\
\text { people }\end{array}$ & Pharaoh & His people \\
\hline $20(9-99)$ & 25 & 12 & 16 & 23 & \\
\hline $26(10-68)$ & 18 & 11 & & 8 & 8 \\
\hline $7(103-157)$ & 29 & 13 & 20 & 3 & 32 \\
\hline $28(3-44)$ & 65 & & & 12 & 8 \\
\hline $10(75-93)$ & 2 & 2 & 9 & 5 & 10 \\
\hline $43(46-56)$ & 7 & & & 6 & 17 \\
\hline $27(7-14)$ & 4 & & & & 6 \\
\hline $11(96-101)$ & & & & 4 & 10
\end{tabular}

Table 3: Personal references in Moses narratives

The occurrence of the multiple referents is conspicuous and makes significant contribution to the cohesion. In each story, beside the main referent, there are others (for example, in Table 3, sorcerers, Moses' people, Pharaoh and his people), which have their own personal and demonstrative references; functioning as main referent in the passages they are mentioned. However, they are related in one way or another to the main referent. Their contribution to cohesion is twofold, one through their own, and secondly through their relation to the main referent. Here, the cumulative effect is well noted. It is mostly realized by the personal references (possessive determiners or adjectives), which provide so many ways to tie and link the text parts together.

\subsubsection{Unmentioned referents}

As some of the referents are not common across all the analysed narratives (and their referential role is limited to the segments in which they were referred to), they are not displayed in the tables. Their contribution to those segments cohesion, however, should not be overlooked. This consideration is based on the fact that a narrative is built of different, yet related segments with each contributing to the wholeness of the narrative. These are in Q 7 (the calf; the people of the idols, and the messenger); Q 20 ('the calf', 'the Samaritan', the fire and the stick), and Q 28 (Moses' mother, the fire, and the stick of Moses, the two 
women and their father). This is normal in a narrative consisting of different segments revolving around one or two principal characters or events, as each segment cohesively contributes to the story formation.

\subsubsection{Interchangeable referent forms}

It is worth noting that in Q 7 and Q 28, the referents, which are related to either pharaoh or his nation, are mentioned in different forms, so they cannot be considered as independent referents. This case, we think, represents the cumulative role of stretching the referent over smaller sections - there are different denominations belonging to one and the same thing (referent). For example, 'children of Israel' or 'those who taken the calf for god' mean the 'people of Moses'. The same applies to 'people of Pharaoh' and 'house of pharaoh' and the 'elite of his people' mentioned in Q 7 and Q 20. This branched referent, so to speak, did not affect the referential relation; on the contrary it strengthened the relation. It can be described as a kind of overlapping in which referents give the text linking strength, tying different, yet related, items in one cascade. It represents another stylistic feature, not yet studied, and it should be considered under the general phenomenon of iltifät. ${ }^{19}$

\begin{tabular}{c|c|c} 
ayah no. & Referent & $\begin{array}{c}\text { Personal pro- } \\
\text { nouns no. }\end{array}$ \\
\hline \multirow{4}{*}{$60-64$} & Moses & 3 \\
\cline { 2 - 3 } & Moses \& his lad & 6 \\
\cline { 2 - 3 } & his lad & 1 \\
\cline { 2 - 3 } & fish & 6 \\
\hline \multirow{4}{*}{ Moses } & 6 \\
\cline { 2 - 3 } & Moses \& wise man & 9 \\
\cline { 2 - 3 } & wise man & 11 \\
\cline { 2 - 3 } & ship & 2 \\
\cline { 2 - 3 } & lad & 4 \\
\cline { 2 - 3 } & wall & 5
\end{tabular}

Table 4: Personal reference in Moses narrative (Q 18)

19 A phenomenon common in the Qur'ān which is related in principle to the occurrence of a shift in the following categories: grammatical person, verb tense, case marker, and change of addressee ('ABDEL HALIM 2001: 188-208). 


\begin{tabular}{c|c|c|c|c}
\multirow{2}{*}{$\begin{array}{c}\text { sura \& } \\
\text { ayahs no. }\end{array}$} & \multicolumn{5}{|c}{ Referents and their respective number in each sura } \\
\cline { 2 - 5 } & Moses & His people & Scared land & Other peoples \\
\hline $5(20-26)$ & 2 & 4 & 7 & 4 \\
\hline \multicolumn{5}{|c}{} \\
\hline $2(67-71)$ & Moses & His people & The cow & God \\
\hline & 5 & 8 & 12 & 10
\end{tabular}

Table 5: Personal references in Moses narratives (Q 2 and 5)

Tables 4 and 5 present the Moses narrative in short segments. Table 4 introduces a different side of the Moses narrative; it consists of two sections, each with multiple referents. All references, which are exclusively personal, are anaphoric. On the other hand, Table 5 displays analysis of short segments of two suras of the Qur'ān (Q 2 and Q 5). In Q 2:67-71 and Q 5:20-26 all references (personal and demonstrative) are anaphoric. Though the narratives are short segments, the reference contributed significantly to the cohesion of the narrative.

In the all narratives so far analysed, we found that all these personal references are anaphoric; their cohesive role is apparent. However, there are some cases of cataphoric reference realized by so called $\underset{\text { damīr }}{a} \check{s}-\check{s}{ }^{\prime}{ }^{\prime} n$ as in Q 20:75; Q 28:37 and Q 27:9. As this pronoun does not refer to a preceding item but to an item coming after, its role in the cohesion is irrelevant. ${ }^{20}$ Finally, the majority of the personal references are personal pronouns consisting of a high number of attached pronouns and possessive determiners (possessive adjectives) as second in order of frequency (results not shown in Tables).

\subsubsection{Demonstrative reference}

The second category of referents, in order of frequency, is the demonstrative. The total number amounted to 28 pronouns distributed as follows ( 6 in Q 20; 5 in Q 26; 5 in Q 7; 8 in Q 28; and one pronoun in each of Q 10; Q 43; Q 27 and Q 11). Passages of Q 18 shown in Table 4 do not have any demonstrative pronoun, and in Table 5 there was only one for Q 2. The majority of these pronouns are anaphorically referring to their respective referents.

All references, whether in lexical or text reference, are anaphoric except in Q 20:17, where the pronoun ذلك 'that' refers cataphorically to the 'stick' of Moses. As regards the text reference, the majority has their referents not in the immediate text (ayah) in comparison to the others found in the near environment (indicated by 'asterisk' in the above Table). In Q 28:15, there are three pronouns of ' هذis'. The first two refer to two immediately preceding nouns; the third one, on the other hand, refers to 'the act of Moses killing his enemy' in the same ayah.

20 HALLidAY \& HASAN 1976: 56, 68.

JAIS • 16 (2016): 199-219 


\begin{tabular}{c|c|c|c|c|c}
\multirow{2}{*}{ sura no. } & \multicolumn{5}{|c}{ Demonstrative pronouns (numbers refer to the ayah inside each sura) } \\
\cline { 2 - 6 } & \multirow{2}{*}{$\begin{array}{c}\text { Lexical } \\
\text { reference }\end{array}$} & \multicolumn{4}{|c}{ Text reference } \\
\cline { 4 - 6 } & this & \multicolumn{2}{|c}{ that } & these & those \\
\hline 20 & $88 ; 17^{*}$ & & $54 \rightarrow 53 ; 76 \rightarrow 75 ; 99$ & & 75 \\
\hline 26 & 34 & & $22 \rightarrow 18-19 ; 67 \rightarrow 63-66$ & $54 \rightarrow 52$ & \\
\hline 7 & $109 ; 131$ & $123 \rightarrow 120-122$ & $141 ; 152$ & $139 \rightarrow 138$ & \\
\hline 28 & $15,32,36$ & $15 *$ & $14 \rightarrow 7-14 ; 28 \rightarrow 27 ;$ & & \\
\hline 10 & $76-77$ & & $32 \rightarrow 31-32$ & & \\
\hline 43 & 52 & & & & \\
\hline 27 & 13 & & & & \\
\hline 11 & & & & & \\
\end{tabular}

Table 6: Demonstrative reference in Moses narratives

\section{Discussion}

On studying ellipsis in a good deal of Qur'ānic narratives from an SFL perspective based on HALLIDAY \& HASAN's Cohesion in English (1976), we found that its role, in the text cohesion, was somewhat not clear (unpublished data). To further our understanding of how cohesion is working in this Qur'ānic genre, ${ }^{21}$ an analysis of other devices, in particular, reference and conjunction seemed necessary to view what roles could they have in the text building. This study, therefore, sheds some light on the extent of reference contribution to the cohesion of the Qur'ānic narratives.

The analysis reveals that both narratives of Moses and Abraham make use of different types of reference in the text. Only the personal and demonstrative, as being the most commonly employed in the text, were analysed. The salient points of this analysis are the use of multiple referents, with their cumulative effect; anaphoric direction of reference; and text reference; and interchangeable use of referents. These together contributed, in varying degrees, to the cohesion of the narratives. Reference is a potentially cohesive relation (HALLIDAY \& HASAN 1976: 309).

As to personal reference, according to HALLIDAY \& HASAN (1976: 43), they consist of personal pronouns, possessive determiners (possessive adjectives), and possessive pronouns. Majority of personal reference this study showed was the personal pronouns, which occurred in bound (attached) and separate forms; the bound (attached) form (of pronouns)

21 It is used here as synonymous of text types in its traditional meaning, and not as understood in the Sydney school of SFL. 
to nouns, verbs and particles is the most frequent. The possessive determiners, on the other hand, are less frequent. Within these two classes, the relation of the third person pronoun to text cohesion is prevalent \& evident because it "is inherently cohesive, in that... it typically refers anaphorically to a preceding item in the text" (HALLIDAY \& HASAN 1976: 48). The analysis displayed this feature clearly where the pronouns of third person in all the segments, long and short, had fallen back on the referents. This simply means that continuity of reference builds up and establishes the 'cohesion', "where the same thing enters into the discourse a second time" (ibid.: 31). Arab grammarians had already highlighted the point that these pronouns are in need of an 'interpreter' to clear up their ambiguity, identifying them and making the text intelligible. In other words, the third person forms imply the presence of its referent somewhere in the text, and its absence renders the text incomplete (ibid.: 49). Being typically textual, the third person role is, therefore, cohesive, comprising "in many texts the most frequent single class of cohesive items" (ibid.). And because it is the basis of realizing cohesion, HALLIDAY \& HASAN affirm that "when we talk of the cohesive function of personal reference therefore, it is the third person forms that we have in mind" (1976: 51).

Closely related to this point is the cumulative effect which stemmed from recurrent use of a certain referent; and thus, through the "network of lines of reference", where "each occurrence being linked to all its predecessors up to and including the initial reference", it contributes considerably to the text cohesion (HALLIDAY \& HASAN 1976: 52). This is noticeable for almost all referents, and in particular, for Moses (Table 3) and Abraham (Table 1). Included within this phenomenon is the existence of four more referents (in each of Tables $1 \& 2$ ) inside each narrative. The role they serve is to create interconnected networks of reference, of their own, within the whole cohesive relations of the narrative. These multiple referents represent an additional cohesive source because their number and density are considered "one of the factors which gives to any text its particular flavour or texture" (HALLIDAY \& HASAN 1976: 52). The inclusion of one referent inside a text with so many ties strengthens the semantic networks that provide the text cohesion.

Central to the role of third person forms, in the text cohesion, is the phority direction of the reference. The analysis shows that the majority of the references are endophoric (anaphoric) and this relation is the only cohesive one because the exophoric, as HALLIDAY \& HASAN (1976: 36) pointed out, links the language with "the context of situation, and not with linking one passage with another to form part of the same text; and thus makes no contribution to the cohesion of a text" (ibid.: 36, 53). The relevance of the anaphoric relation to the coherence derives from a link it provides "with a preceding portion of the text" (ibid.: 50), because of its significance in the text forming, since "all endophoric reference contributes to the making of a text" (HALLIDAY 2002 [1977]: 39).

The cataphoric reference, on the other hand, is limited to the damīr $a \check{s}-\breve{s} a$ 'n of which is more related to rhetorical purposes. Thus it provides no contribution to the text cohesion, because it is a "realization of a grammatical relationship within a nominal group" (HALLIDAY \& HASAN 1976: 56; 68). The exception is the textual cataphora that is cohesive realized by demonstrative reference (ibid.). The cataphoric reference is not common in the texts analysed in comparison to the anaphoric relation. This also applies to the exophoric reference, which has limited use in our texts. 
A further means identified in this study is a 'text reference' in which reference items not only fall back on a (single) lexical referent, but take a part of a text as their referent. This function is mostly realized by demonstrative reference, and in particular, by the pronouns $h \bar{a} \underline{d} \bar{a}$ 'this' and $\underline{d} \bar{a} l i k a$ 'that', ${ }^{22}$ where they refer to a distant portion of a text, creating links with the rest, and thus holding them together. Arab linguists in their elaboration of the Qur'ān exegesis had realized that demonstrative pronouns semantically establish a tie between the text parts. This tie covers both the lexical and textual references. In our study, we found that the text reference, realized by pronouns of $h \bar{a}^{\prime} u l \bar{a}^{\prime}$ 'these', 'ula' $i k a$ 'those', 'that' and 'this', is the most notable. Hence, in addition to the personal reference, the demonstrative reference is another resource providing a linking tie between the passages of a text to build up its cohesion; which is realized through bringing together these remote, yet, semantically related elements of the texts. Though their frequency of use is not as much as the personal reference in the texts analysed, the role they serve into the text cohesion is considerable.

Being one element of the textual metafunction, reference role in the text creating is essential because through this metafunction a difference is made between language in abstract and language in use in that the language has relevance to its environment (HALLIDAY 2002 [1977]: 29). To further our understanding of the narratives making, we set up to analyse the textual metafunction of some of these narratives to reveal how this metafunction enables organizing the semantic options of both the experiential and interpersonal metafunctions to convey its message.

A comparison between Abraham and Moses suras would reveal some differences in the way they use reference as a cohesive device in presenting the narratives. Moses narratives are more sophisticated in their structure, in the employment of personal references, and the multiple referents, and interchangeability of various forms of one referent. The level of reference in the Moses narratives is more dense, so to speak, and hence more cohesive than in the Abraham's ones.

\section{Concluding remarks}

Viewed from an SFL perspective, reference is a relation whose function is to match the semantic rather than the grammatical aspects of the relevant items in a text. It is one element, of the cohesive relations, used by the textual metafunction to organize the text and provides its texture. Based on our study, we consider reference as one of the cohesive devices frequently employed by the Qur'ānic narratives. The findings of this study, which examined some of the reference elements, can be summarized as follows. Arabic linguistic Tradition touched, explained in light of SFL principles, on some insightful observations on the importance of referential relations of both the personal and demonstrative pronouns in understanding the Qur'ānic text. Secondly, reference, viewed as a grammatical device of the cohesion, played an essential role in creating and organizing the text of the analysed narratives. This is expressed by both personal and demonstrative reference. The personal

22 In English, 'that' is always anaphoric, as compared to 'this', which may be either way: anaphoric and cataphoric (HALLIDAY \& HASAN 1976: 68). 
reference is the commonly used in this Qur'ānic genre, and in particular the personal pronouns. One salient feature (of these pronouns) is their anaphoric relation, which is considerably essential to the text cohesion. Another point is the use of multiple referents, which creates a cumulative effect in that it enables building up networks of links tying the text parts. This effect, on the other side, facilitates its understanding by the addressees.

The demonstrative reference is also evident in that the 'text reference', characteristic of demonstrative pronouns, brings distant, yet related, parts of a text together; strengthening thus the semantic relations between them. Finally, interchangeable use of referents provides the text with another cohesive resource. Taken together, the various reference relations had built interconnected networks of linked meanings. To get a complete picture of the cohesive reference role in the Qur'ān, more narratives need to be examined, as well as other genres or text types investigated. By setting religious considerations aside, research based on the systemic functional linguistics approach has been helpful for addressing one aspect of the controversial issue of the Qur'annic coherence. This implies that the Linguistic resources of the Qur'ān are analysable within the principles of SFL theory. ${ }^{23}$

\section{References}

'ABD AL-HaLİM, Muhammad. 2001. Understanding the Qur'an: themes and styles. I.B. Tauris \& Co. Ltd., London.

ABŪ ZAYD, Nāṣir Ḥāmid. 1995. al-Nāṣ wal-sulțah wal-ḥaqūqah. Arabic Cultural Centre, Casa Blanca, Morocco \& Beirut, Lebanon.

- 1995. al-Tafkì fi zaman al-takfir, $2^{\text {nd }}$ ed. Madbouly Bookshop, Cairo.

- . 1996. al-Ittijāhāt al-'aqliyyah fì tafsìr al-Qur'ān, $3^{\text {rd }}$ ed. Arabic Cultural Centre, Casa Blanca, Morocco \& Beirut, Lebanon.

- 2003. "The Dilemma of the Literary Approach to the Qur'ān". Alif: Journal of Comparative Poetics, 23: 8-47.

al-'Alawī. al-Minhāăğ fi šarh ğumal al-Zağğḡăǧĩ / ed. H. A. Nagy. Riyadh: Maktabat ar-Rušūd, 2009.

al-'Andalusī, 'Abū Hayyān. Tafsīr al-baḥr al-muhīṭ / ed. A. A. 'ABD AL-MAWĞŪD \& A. M. MứAwwAḌ. Beirut: Dār al-Kutub al-'ilmiyya, 1993.

al-'ASTARĀBĀDī. Šarhh al-raḍ̄ 'alā al-Kāfiyya, $2^{\text {nd }}$ ed. / ed. Y. H. 'UMAR. Qar Yunis University: Benghazi, 1996.

Awa, Salwa M. el- $\rightarrow$ EL-AwA.

BAKER, Mona. 1992. In Other Words: A Course Book on Translation. Routledge, London.

Brown, Gillian / Yule, George. 1988. Discourse analysis. Cambridge University Press, Cambridge.

Christiansen, Thomas. 2011. Cohesion: A Discourse Perspective. Peter Lang, Bern \& New York.

EgGINs, Suzanne. 2004. An Introduction to Systemic Functional Linguistics. $2^{\text {nd }}$ edition. Continuum, New York.

23 Applying SFL to the Qur'ān: Textual Metafunction in Some of the Qur'änic Narratives of Abraham (Thesis by the first author).

JAIS • 16 (2016): 199-219 
EL-Awa, Salwa M. S. 2006. Textual Relations in the Qur'ān: Relevance, coherence and structure. Routledge, London.

FAWCETT, Peter. 1997. Translation and Language: Linguistic Theories Explained. ST Jerome Publishing, Manchester.

Halliday, Michael. 1994. An Introduction to Functional Grammar, $2^{\text {nd }}$ edition. E. Arnold, London.

— . 2002. Linguistic Studies of Text and Discourse / ed. Jonathan J. WeBSTER. Continuum, London.

—/ HASAN, Ruqaiya. 1976. Cohesion in English. Longman, London.

- I HASAn, Ruqaiya. 1989. Language, context, and text: Aspects of language in a social-semiotic perspective. Oxford University Press, Oxford.

- / Matthiessen, Christian. 2004. An Introduction to Functional Grammar, $3^{\text {rd }}$ edition. Arnold, London.

ḤASAN, 'Abbās. 1974. an-Naḥw al-wafy, $3^{\text {rd }}$ edition. Dār al-Ma'ārif, Cairo.

HASSĀN, Tammām. 2005. "Proximity and distance in the Qur'ānic text". Journal of Qur'ānic Studies 7/2: $168-188$.

—. 1993. al-Bayān fī Rawā̄̄à al-Qur'ān. ‘'̄lam al-Kutub, Cairo.

—. 1994. al-Luġa al-`arabiyya: ma`nāhā wa-mabnāhāa. Dār al-Taqāfa, Casablanca.

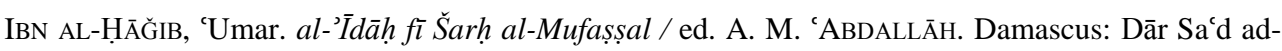
Dīn, 2005.

IBN HišĀM, 'Abū Muḥammad. Muginnī al-labīb / ed. A. M. AL-XAṬ̄ī. Kuwait: Al-Mağlis al-wațanī lil-țaqāfa wa'l-funūn wa'l-'ādāb, 2000.

IBN YA'Īš. Šarh al-Mufașṣal / ed. A. B. YA`QūB. Beirut: Dār al-kutub al-'ilmiyya, 2001.

MIR, Mustansir. 1988. "The Qur’ān as Literature”. Religion \& Literature, 20/1: 49-64.

SīBAWAyHI, 'Abū Bišr 'Amr b. 'Uțmān b. Qanbar al-Bașrī. al-Kitāb / ed. 'A. S. HĀRūN. Cairo: Maktabat al-Xānğī, 1988.

as-SUHAYLĪ, 'Abd Allāh. Natā̉iğ al-fikr fì al-naḥw / ed. A. A. 'ABD AL-MAWĞŪD \& A. M. MU'AWWAḌ. Beirut: Dār al-kutub al-'ilmiyya, 1992.

TABOAdA, María Teresa. 2004. Building Coherence and Cohesion: Task-oriented Dialogue in English and Spanish. John Benjamins, Amsterdam \& Philadelphia.

TANSKAnEn, Sanna-Kaisa. 2006. Collaborating towards Coherence. Lexical cohesion in English Discourse. John Benjamins Publishing Company, Amsterdam.

Thompson, Geoff. 2004. Introducing Functional Grammar, $2^{\text {nd }}$ edition. Arnold, London.

az-ZAMAXŠAR̄̄. Tafsīr al-Kaššāf, $3^{\text {rd }}$ ed. / ed. Xalīl Ma’mūn Šīhāā. Beirut: Dar al-Ma'rifa,2009.

(C) Zaid Shihab Alamiri and Peter Mickan, University of Adelaide, Australia

\zaid.alamiri@adelaide.edu.au \ | \ peter.mickan@adelaide.edu.au 